\title{
Auditor Reports, Audit Fees, and CEO Compensation
}

\author{
Yinghong Zhang ${ }^{1} \&$ Chunwei Xian ${ }^{2}$ \\ ${ }^{1}$ Lally School of Management, Rensselaer Polytechnic Institute, Troy, New York, USA \\ ${ }^{2}$ College of Business and Management, Northeastern Illinois University, Chicago, Illinois, USA \\ Correspondence: Yinghong Zhang, Lally School of Management, Rensselaer Polytechnic Institute, Troy, New \\ York, NY 12180, USA. Tel: 1-518-276-2342. E-mail: zhangy22@rpi.edu
}

Received: May 27, 2014

doi:10.5539/ijef.v6n9p1
Accepted: June 23, 2014

Online Published: August 25, 2014

\begin{abstract}
We run the regressions of CEO cash and total compensation on changes in audit opinions and changes in audit or total fees. Our findings show that the incidence of non-standard opinions reduces cash or total compensation. Then after the issuance of going concern opinions, CEOs receive more current incentive compensation relative to total compensation. Finally, there is a positive correlation between changes in cash or total compensation and changes in audit or total fees. Our results show that the audit opinion is one determinant of CEO compensation while auditors charge higher audit or total fees to compensate for the high litigation risk associated with increases in CEO compensation.
\end{abstract}

Keywords: CEO compensation, cash compensation, total compensation, audit opinions, modified opinions, going-concern opinions, audit fees, total fees

\section{Introduction}

Auditing is a profession that should incorporate enough audit risk and ensure effective audit scope. According to Wallace (1987), auditors play three roles-monitoring role, signaling role and insuring role. Monitoring role means that auditors watch as "public watchdog" to monitor managers' behaviors to align with shareholders' benefits. To be specific, it means that auditors should prevent managers from engaging in earning management activities. Signaling role means that auditors should provide timely and useful information to the public. Insuring role means that auditors should comply with legal and regulatory requirements.

In some circumstances, auditors do not think that the monitoring role is their most important role. Previous studies (e.g., DeFond \& Subramanyam, 1998) find that auditors' preference for conservative accounting choices is not based on the desire to control earnings management but the desire to avoid future litigation. The choice of accounting treatments and thus the extent of earnings management differ across auditors based on factors such as individual assessment of client risk and relative risk propensities.

Our study utilizes audit opinions and audit fees as proxies for the litigation risk of auditors' clients. We investigate the impact of audit opinions and audit fees on CEO compensation. To be specific, we examine changes in CEO compensation based on different audit opinions and audit or total fees. Our sample period is 1993-2004 for the investigation of impacts of audit opinions that are classified by standard and nonstandard opinions. Then we further restrict our sample period to 2000-2004 when we examine impacts of going concern opinions and of audit or total fees. Our sample period (including years prior to the effectiveness of Sarbanes-Oxley Act and the transition year for the compliance of this act) helps me to investigate the impacts of audit opinions and audit fees on CEO compensation prior to the complete implementation of the Sarbanes-Oxley Act (SOX).

We find that the existence of modified opinions is associated with lower CEO cash compensation and total compensation. The explanation is that modified opinions are the indicators of poor firm performance or financial distress. The portion of CEO compensation decreased by the unsatisfied firm performance or financial condition dominates the portion of CEO compensation increased by earnings management. Our analysis of going concern opinions implies that after the issuance of going concern opinions, CEOs are offered more current incentive compensation compared to total compensation. This indicates that CEOs prefer short-term compensation to long-term compensation after the issuance of going concern opinions that contain information about potential bankruptcy. 
Finally, we show that changes in cash or total compensation are the increasing function of changes in audit or total fees. The economic meaning is that discretionary accruals, one proxy for audit risk, are positively related to audit or total fees. Auditors would rather charge higher audit or total fees to pay for higher audit risk than ask management to reduce the level of discretionary accruals.

Generally speaking, our results show some evidence that auditors do not function very well as the monitoring role because auditors do not modify managerial discretion of increasing compensation through accounting choices or discretionary accruals. Auditors even claim for additional audit or total fees to allow managers to manipulate earnings. Furthermore, modified opinions and going concern opinions are able to predict the level and structure of CEO compensation.

Our study is useful to compare auditors' behaviors as the monitoring role. Section 301 of SOX allows the audit committee (instead of managers) to have the authority to hire the auditor. Therefore, after the enactment of SOX, auditors should strengthen their monitoring role to be more responsible to shareholders.

This study also adds to the compensation literature by showing that audit opinions and audit fees are additional determinants of CEO compensation. Finally our study contributes to the auditing literature by showing that CEO compensation can affect auditors' judgment about audit opinions and audit fees.

\section{Literature}

\subsection{Auditor Opinions}

Previous studies focus on designing models to predict audit opinions. Dopuch, Holthausen and Leftwich (1987) develop the benchmark model to predict audit opinions. They find that companies receiving qualified reports are more likely to have current year loss, larger amounts of inventories, higher leverage, smaller market adjusted-returns and beta, and larger stock return volatility. Mutchler (1985) and Mutchler, Hopwood and McKeown (1997) indicate that the existence of going concern opinions is positively correlated with probability of bankruptcy, prior years of going concern opinions, debt covenant default, negative news from the media, days between statement date and audit-report date, and negatively correlated with firm size, days between audit-report date and bankruptcy filing date.

Some studies address the influence of accounting accruals on audit opinions. Francis and Krishnan (1999) document that auditors are more likely to issue modified opinions (Note 1) of asset realization uncertainties or going concern problems to companies having high accruals. Bradshaw, Richardson and Sloan (2001), to the opposite, show that high levels of working capital accruals lead to a greater incidence of "clean" opinions (Note 2).

One related study is done by Lennox (1998). Using a sample of U.K. companies, he finds that modified reports are negatively related to compensation of top directors. He also indicates that audit reports comprise of larger economic effects on executive compensation than accounting and market variables.

\subsection{Audit Fees}

Similar to the research on audit opinions, traditional literature on audit fees (Note 3) aims at identifying the model of pricing audit services. Simunic (1980) and Palmrose (1986) find that audit fees grow up with increases in firm size, business complexity (Note 4), receivables and inventories, incidence of losses, incidence of modified opinions, number of reports provided by the auditor, and big eight auditors. Audit fees decline if the client participates during the audit.

Recent studies pay attention to non-audit fees due to the regulatory concern that non-audit services might impair auditor independence. The results are mixed. Using earnings management as the proxy for auditor independence, Frankel, Johnson and Nelson (2002) show that non-audit fees are positively related to the magnitude of discretionary accruals while Ashbaugh, LaFond and Mayhew (2003) and Chung and Kallapur (2003) suggest that non-audit services do not violate auditor independence. DeFond, Raghunandan and Subramanyam (2002) also imply that non-audit fees do not relate to the inclination to issue going concern opinions, another proxy for auditor independence.

Two useful studies are those of Gul, Chen and Tsui (2003) and Chen, Krishnan and Su (2002). Based on Australian firms, Gul, Chen and Tsui (2003) show that discretionary accruals are positively associated with audit fees. Chen, Krishnan and $\mathrm{Su}$ (2002) document a positive relationship between non-audit fees and the proportion of performance-based compensation paid to top five executives. 


\section{Hypothesis}

\subsection{The Association of Compensation and Audit Opinions}

The auditor-client negotiation theory suggests that modified opinions (qualified, adverse, or unqualified opinions with the explanatory paragraph) result from the failure of the auditor-client negotiation. The client refuses to accept any revision proposed by the auditor (Antle \& Nalebuff 1991; Gibbins, Salterio, \& Webb, 2001). On one hand, auditors usually issue modified opinions to companies that are financially distressed, report losses or perform questionable accounting applications (Dopuch et al., 1987; Mutchler, 1985; Mutchler et al., 1997). Therefore, for companies with modified opinions, compensation should be lower due to the poor economic performance. The study of Lennox (1998) is consistent with this conjecture. On the other hand, accrual levels are higher in firms subject to SEC enforcement actions for GAAP violations (Bradshaw et al., 2001). Francis and Krishnan (1999) show that auditors are more likely to issue modified opinions to firms with larger magnitudes of accruals, especially income-increasing accruals. Nevertheless, Bradshaw et al. (2001) imply that firms with high levels of accruals are associated with the prevalence of clean opinions, though the association becomes weaker for subsequent audit opinions. Due to the diverse findings of previous studies, we predict no direction about the compensation-opinion relationship and our hypothesis is:

\section{H1: Changes in compensation is not associated with the incidence of modified audit opinions.}

We specifically focus on going concern opinions. Companies having going concern problems tend to violate debt covenants or go to bankruptcy (Mutchler, 1985; Mutchler et al., 1997). Since companies face the probability of liquidation in the short run, management is more likely to earn short-term compensation instead of long-term compensation. Our further hypothesis about going concern opinions is:

Hla: The ratio of current compensation to total compensation is positively associated with the incidence of going concern opinions.

\subsection{The Association of Compensation and Audit / Total Fees}

The impact of audit fees on compensation is in two-fold. On one hand, the investigation of discretionary accruals needs subjective judgments. This consumes more efforts of auditors and requires higher audit fees (Gul et al., 2003). In addition, the level of discretionary accruals is positively correlated with the probability of accounting misstatements. Thus high-accrual firms are related to high inherent audit risk (Francis \& Krishnan 1999). Auditors compensate high audit risks for high audit fees. Since managers use discretionary accruals to overstate earnings and thus increase compensation, we expect a positive relationship between compensation and audit fees. On the other hand, the level of audit fees is tied to audit brand names because big five accounting firms charge audits fee premiums (Simunic, 1980; Palmrose,1986). Since big five auditors are more likely to restrict the level of discretionary accruals (Francis et al., 1999; Becker, DeFond, Jiambalvo, \& Subramanyam, 1998; Kim, Chung, $\&$ Firth, 2003). Therefore, when audit fees are higher, compensation is lower due to the failure for management to opportunistically increase earnings.

Total fees affect changes in compensation in the same way as audit fees. Audit-related fees are also spent for the attestation and assurance services. Non-audit fees vary in the same direction as audit fees due to the knowledge spillover effect (Simunic, 1980).

Consequently, we make no prediction about the association of compensation with audit fees (total fees) and our hypothesis regarding audit fees (total fees) is:

H2: There is no relation between changes in compensation and changes in audit fees (total fees).

\section{Research Design}

I establish the equation of compensation based on audit information after controlling economic condition of the company, industries and years. Thus the function about compensation is the following:

Compensation variables $=f$ (auditor change variables, economic variables, industry dummies, year dummies)

There are two measures of compensation variables: cash compensation (CASHCOMP) and total compensation (TOTALCOMP). Total compensation is overall compensation management has earned while cash compensation captures the current component of total compensation.

According to Core et al. (1999), economic variables include natural log of sales (SALES), book to market ratio (BM), return on assets (ROA), one-year stock returns (TRS1YR), standard deviation of ROA (SROA) and standard deviation of one-year stock returns (STRS1YR). SALES is the proxy for firm size and complexity. BM represents the investment opportunity set. ROA and TRS1YR measure the firm performance. SROA and 
STRS1YR control for firm risk.

The following equation is adopted to check H1 (Note 5). We use the dummy variable MOD to investigate the relationship between audit opinions and CEO compensation. MOD equals one for modified opinions, i.e. qualified opinions, adverse opinions or unqualified opinions with the explanatory paragraph.

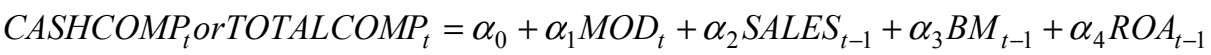

$$
\begin{aligned}
& +\alpha_{5} \operatorname{TRS}_{1 Y R_{t-1}}+\alpha_{6} S R O A_{t-1}+\alpha_{7} S T R S 1 Y R_{t-1} \\
& +\sum \alpha_{j} \text { Industrydummies }_{j}+\sum \alpha_{k} \text { Yeardummies }_{k}+\varepsilon
\end{aligned}
$$

To examine H1a, we use a new dependent variable to replace CASHCOMP or TOTALCOMP. The dependent variable is MIX, the ratio of current incentive compensation to total compensation (Note 6). We also change MOD into GOCO (the indicator variable coding one for going concern opinions). The model relating to H1a is:

$$
\begin{aligned}
\text { MIX }_{t}= & \alpha_{0}+\alpha_{1} \text { GOCO }_{t}+\alpha_{2} \text { SALES }_{t-1}+\alpha_{3} \text { BM }_{t-1}+\alpha_{4} \text { ROA }_{t-1}+\alpha_{5}{\text { TRS } 1 Y R_{t-1}} \\
& +\alpha_{6} \text { SROA }_{t-1}+\alpha_{7}{\text { STRS } 1 Y R_{t-1}}+\sum \alpha_{j} \text { Industrydummies }_{j} \\
& +\sum \alpha_{k} \text { Yeardummies }_{k}+\varepsilon
\end{aligned}
$$

Finally, to examine the association of CEO compensation with audit / total fees (H2), we use a different research approach. First, we regress CASHCOMP / TOTALCOMP on all variables except dummy variables for auditor changes or audit opinions (Note 7). Second, we establish new equations whose dependent variables are the two residuals R1 (residual from the CASHCOMP regression) and R2 (residual from the TOTALCOMP regression) and whose independent variables are DCHAUDFEE / DCHTOTFEE (changes in audit / total fees, deflated by total assets), CHPMDA (changes in performance-matched discretionary accruals (Note 8), deflated by total assets), and $\mathrm{CH}$ (dummy variable for auditor changes). The model for examining $\mathrm{H} 2$ is specified as follows:

$$
\begin{aligned}
R 1_{t} \text { orR }_{t}= & \alpha_{0}+\alpha_{1} \text { DCHAUDFEE }_{t} \text { orDCHTOTFEE }_{t}+\alpha_{2} \text { CHPMDA }_{t}+\alpha_{3} C H_{t-1} \\
& +\sum \alpha_{j} \text { Industrydummies }_{j}+\sum \alpha_{k} \text { Yeardummies }_{k}+\varepsilon
\end{aligned}
$$

\section{Sample}

We first obtain all compensation data from the ExecuComp during the sample period of 1993-2004 (Note 9). We focus on CEO compensation because CEOs have the authority to manipulate earnings and can significantly affect firm performance (Gaver \& Gaver, 1998). We then obtain financial information, stock returns and audit opinions from the Compustat. Finally, we collect information about going-concern opinions and audit fees from the Audit Analytics. The regressions about Equation 2 and 3 are only for the sample period of 2000-2004 because Audit Analytics only has the data from 2000 to 2004.

Table 1. Sample selection

Panel A.

\begin{tabular}{lcc}
\hline Selection Criteria & No of observations \\
\hline Panel A: Audit Opinions & & 18872 \\
Obs of CEO total/cash compensation and the mix ratio & 1438 & \\
Less: Obs without info. on audit opinions & 4426 & \\
Obs without the financial and stock price data & & 13008 \\
Total Observations: Obs available for the regressions on equation 6 & 8860 & \\
From Total Observations Less: Obs without info. on going concern opinions & & 4148 \\
Obs available for the regression on equation 7 & & \\
\hline
\end{tabular}

Panel B. Audit / total fess

\begin{tabular}{lrr}
\hline Obs of residuals & 7356 \\
\hline Less: Obs without data of performance discretionary accruals & 2914 & \\
Obs without info. on auditor changes & 0 & \\
Obs without info. on audit / total fees & 1438 & 3004 \\
Obs available for the regressions on equation 8 & & \\
\hline
\end{tabular}


Table 1 indicates the sample selection (Panel A and B are for the selections of audit opinions and audit / total fees respectively). In Panel A, beginning with the 18,872 observations of compensation data, we delete 1,438 observations lack of audit opinion data and 4,426 observations lack of financial and stock market data to run the regression on nonstandard opinions (Equation 1). Then we further eliminate 8,860 observations lack of data of going concern opinions to examine the relation between the mix ratio and going concern opinions (Equation 2). In Panel B, there are 7,356 observations of residuals from the regressions of cash / total compensation on financial and market variables. Then we exclude 2,914 observations of missing discretionary accrual data and 1,438 observations of missing fee data to come up with 3,004 observations to investigate the impact of audit / total fees (Equation 3).

\section{Descriptive Statistics}

6.1 Frequency Analysis

Table 2. Frequency of audit opinions

Panel A. Sample period $=1993-2004$

\begin{tabular}{ccc}
\hline Frequency & Standard Opinions & Non-Standard Opinions $^{1}$ \\
\hline 1993 & 64 & 182 \\
1994 & 329 & 474 \\
1995 & 731 & 478 \\
1996 & 1018 & 241 \\
1997 & 1052 & 149 \\
1998 & 1117 & 125 \\
1999 & 1114 & 159 \\
2000 & 1062 & 210 \\
2001 & 903 & 365 \\
2002 & 457 & 863 \\
2003 & 401 & 905 \\
2004 & 346 & 263 \\
Total & 7480 & 4414
\end{tabular}

Panel B. Sample period $=2000-2004$

\begin{tabular}{cccccccc}
\hline & 2000 & 2001 & 2002 & 2003 & 2004 & Total \\
\hline Going Concern Opinions & 0 & 13 & 14 & 8 & 1 & 36 \\
\hline
\end{tabular}

Note. Non-standard Opinions: Qualified opinion, adverse opinion or unqualified opinion with the explanatory paragraph.

Table 2 shows variations of audit opinions across the sample years. Panel A examines standard / non-standard opinions during 1993-2004. In general, number of standard opinions $(7,480)$ is more than number of non-standard opinions (4,414). However, in 1993, 1994, 2002, and 2003, number of standard opinions is fewer than number of non-standard opinions probably because auditors are more conservative during these years. Relative to other years, during 1996-2000 observations of standard opinions have the highest frequencies while observations of non-standard opinions have the lowest frequencies. Panel B provides frequency of going concern opinions during 2000-2004. Number of going concern opinions goes up from 0 in 2000 to 13 in 2001 and 14 in 2004, then goes down to 8 in 2003 and 1 in 2004.

Table 3. Mean of audit fees and total fees (sample period $=2000-2004)$

\begin{tabular}{llcc}
\hline & Audit Fees & Total Fees & Obs \\
\hline 2000 & $\$ 1,493,419$ & $\$ 7,387,816$ & 7 \\
2001 & $\$ 1,346,303$ & $\$ 4,534,902$ & 558 \\
2002 & $\$ 1,475,713$ & $\$ 3,469,121$ & 910 \\
2003 & $\$ 1,887,621$ & $\$ 3,358,678$ & 958 \\
2004 & $\$ 3,101,333$ & $\$ 4,555,872$ & 571 \\
Total & $\$ 1,891,254$ & $\$ 3,846,283$ & 3004 \\
\hline
\end{tabular}


Table 3 presents mean audit fees / total fees by years during 2000-2004. The mean audit fees and mean total fees for the total sample are about $\$ 1.9$ million and $\$ 3.8$ million respectively. There are a few observations in 2000 (7) compared to other years (558 in 2001, 910 in 2002, 958 in 2003, 571 in 2004). Mean audit fees slightly decrease from 2000 to 2001 and then consistently increase from 2001 to 2004 . Mean audit fees grow up by about $\$ 1.2$ million from 2003 to 2004 due to the internal control requirements by the Sarbanes-Oxley Act (Note 10). Mean total fees consistently decrease during 2000-2003 and then increase from 2003 to 2004 by almost the same amount as changes in mean audit fees.

\subsection{Descriptive Statistics}

Table 4. Descriptive statistics

\begin{tabular}{|c|c|c|c|c|c|c|}
\hline Variable & Obs & Mean & Std. Dev. & $25 \%$ & Median & $75 \%$ \\
\hline $\mathrm{CASHCOMP}_{\mathrm{t}}$ & 12990 & 6.839 & 1.011 & 6.342 & 6.844 & 7.362 \\
\hline TOTALCOMP $_{t}$ & 12990 & 7.688 & 1.179 & 6.919 & 7.629 & 8.423 \\
\hline $\operatorname{MIX}_{\mathrm{t}}$ & 4148 & 0.644 & 0.262 & 0.517 & 0.720 & 0.841 \\
\hline $\mathrm{R} 1_{\mathrm{t}}$ & 3004 & 0.000 & 0.001 & -0.000 & -0.000 & 0.000 \\
\hline $\mathrm{R} 2_{\mathrm{t}}$ & 3004 & -0.000 & 0.005 & -0.001 & -0.000 & 0.001 \\
\hline $\mathrm{MOD}_{\mathrm{t}-1}$ & 13008 & 0.339 & 0.474 & 0 & 0 & 1 \\
\hline $\mathrm{GOCO}_{\mathrm{t}-1}$ & 4148 & 0.009 & 0.092 & 0 & 0 & 0 \\
\hline DCHAUDFEE $_{t}$ & 3004 & -0.000 & 0.003 & 0.000 & 0.000 & 0.000 \\
\hline DCHTOTFEE $_{\mathrm{t}}$ & 3004 & -0.000 & 0.004 & -0.000 & 0.000 & 0.001 \\
\hline SALES $_{\mathrm{t}-1}$ & 12990 & 7.062 & 1.595 & 6.033 & 6.998 & 8.083 \\
\hline $\mathrm{BM}_{\mathrm{t}-1}$ & 12990 & 0.521 & 8.827 & 0.258 & 0.426 & 0.645 \\
\hline $\mathrm{ROA}_{\mathrm{t}-1}$ & 12990 & 0.052 & 0.162 & 0.020 & 0.054 & 0.100 \\
\hline TRS1YR $_{\mathrm{t}-1}$ & 12990 & 0.219 & 2.476 & -0.140 & 0.094 & 0.363 \\
\hline $\mathrm{SROA}_{\mathrm{t}-1}$ & 12990 & 6.451 & 11.407 & 1.924 & 3.521 & 6.483 \\
\hline STRS1YR ${ }_{\mathrm{t}-1}$ & 12990 & 227.614 & 5317.110 & 25.531 & 37.519 & 59.005 \\
\hline CHPMDA $_{t}$ & 3004 & 0.013 & 3.935 & -0.214 & 0.001 & 0.214 \\
\hline $\mathrm{CH}_{\mathrm{t}-1}$ & 12990 & 0.046 & 0.209 & 0 & 0 & 0 \\
\hline
\end{tabular}

Table 4 provides descriptive statistics for variables in Equation 1-3. For equation 1 and 2, about one-third of observations are for nonstandard opinions during 1993-2004 (mean MOD =0.339) and almost one percent of observations are associated with going concern opinions during 2000-2004 (mean GOCO =0.009). Also during 2000-2004, more than half of total compensation is current incentive compensation (MIX $=0.644$ ).

For Equation 3, variables other than financial and market variables can only explain a very small percentage of variations of CEO compensation (mean R1 $=0.000$; mean R2 $=-0.000$ ). Furthermore, after deflated by total assets, audit fees and total fees almost remain the same across years (mean DCHAUDFEE $=-0.000$; mean DCHTOTFEE $=-0.000$ ). Finally, in general, changes in performance-matched discretionary accruals occupies about $13 \%$ of total assets (mean CHPMDA $=0.013$ ).

\section{Empirical Findings}

\subsection{Audit Opinions}

Table 5. OLS regressions for audit opinions

Panel A. Sample period $=1993-2004$ (Equation 1)

\begin{tabular}{lcccc}
\hline & \multicolumn{2}{c}{ Dependent Variables $=$ Log $(\text { Cash Compensation })_{\mathrm{t}}$} & Dependent Variables $=$ Log $(\text { Total Compensation })_{\mathrm{t}}$ \\
\cline { 2 - 5 } & Coeff. & t-stat & Coeff. & t-stat \\
\hline Intercept & 5.204 & $71.16^{* * *}$ & 5.159 & $-2.47^{* *}$ \\
MOD $_{\mathrm{t}-1}$ & -0.017 & $-1.56^{*}$ & -0.038 & $94.11^{* * *}$ \\
SALES $_{\mathrm{t}-1}$ & 0.319 & $98.62^{* * *}$ & 0.442 & $-4.07^{* * *}$ \\
BM $_{\mathrm{t}-1}$ & -0.001 & -1.51 & -0.006 & $3.01^{* * *}$ \\
ROA $_{\mathrm{t}-1}$ & 0.016 & 0.54 & 0.142 & $15.12^{* * *}$ \\
TRS1YR $_{\mathrm{t}-1}$ & 0.032 & $8.48^{* * *}$ & 0.151 & $12.04^{* * *}$ \\
SROA $_{\mathrm{t}-1}$ & -0.000 & -0.30 & 0.009 & 1 \\
\hline
\end{tabular}




\begin{tabular}{|c|c|c|c|c|}
\hline STRS1YR $_{\mathrm{t}-1}$ & 0.000 & $5.67^{* * *}$ & 0.000 & $5.68^{* * *}$ \\
\hline Obs & & & & \\
\hline Adj. $R^{2}$ & & & & \\
\hline
\end{tabular}

Panel B. Sample period $=2000-2004$ (Equation 2)

\begin{tabular}{lcc}
\hline & \multicolumn{2}{c}{ Dependent Variables = MIX } \\
Coefficient & T-statistics \\
\hline Intercept & 0.143 & $2.73^{* * *}$ \\
GOCO $_{\mathrm{t}-1}$ & -0.065 & $-1.93^{*}$ \\
SALES $_{\mathrm{t}-1}$ & 0.059 & $27.51^{* * *}$ \\
BM $_{\mathrm{t}-1}$ & -0.000 & $-1.76^{*}$ \\
ROA $_{\mathrm{t}-1}$ & 0.154 & $6.31^{* * *}$ \\
TRS1YR $_{\mathrm{t}-1}$ & 0.001 & 1.52 \\
SROA $_{\mathrm{t}-1}$ & 0.002 & $6.75^{* * *}$ \\
STRS1YR & -0.000 & $-3.50^{* * *}$ \\
Obs & \multicolumn{3}{|}{} \\
Adj. $\mathrm{R}^{2}$ & 3859 & \\
\hline
\end{tabular}

Note. $* * *, * *, *$ Coefficient is significant at the one percent level, the five percent level, the ten percent level respectively (one-tailed where signs are predicted, two-tailed otherwise).

Table 5 demonstrates regression results of Equation 1 (Panel A) and Equation 2 (Panel B). In Panel A, only SALES, TRS1YR and STRS1YR are significant in the cash compensation regression while all financial and stock market variables are significant in the total compensation regression. Coefficient on MOD is significantly negative in both the cash and total compensation regressions (Cash compensation regression: coefficient = -0.017 ; $\mathrm{t}$-statistics $=-1.56$; $\mathrm{p}$-value $<0.1$. Total compensation regression: coefficient $=-0.038 ; \mathrm{t}$-statistics $=-2.47$; p-value $<0.05$ ). This rejects H1 and implies that existence of modified opinions is associated with less cash / total compensation. In particular, after receiving modified opinions, compared to prior cash and total compensation, cash compensation and total compensation shrink to approximately $98 \%$ (exp(-0.017)) and $96 \%$ $(\exp (-0.038))$ respectively. The economic implication is that non-standard opinions are the indicator of poor firm performance, which cuts off CEO compensation.

In Panel B, all financial and stock market variables have the explanatory power except TRS1YR. The negative coefficient on STRS1YR indicates that the higher the firm risk, the more likely that a CEO receives current incentive compensation to offset the risk. The variable of interest is GOCO. Consistent with H1a, coefficient on GOCO has the significantly negative sign. This indicates that a CEO is inclined to receive current incentive compensation (especially bonus) relative to long-term compensation when the company is likely to go to bankruptcy in the near future.

\subsection{Audit Fees / Total Fees}

Table 6. OLS regressions for audit / total fees (Sample Period $=2000-2004$ )

Panel A. Dependent variables $=R 1_{t}$ (Equation 3$)$

\begin{tabular}{|c|c|c|c|c|}
\hline & \multicolumn{2}{|c|}{$\mathrm{R} 1_{\mathrm{t}}$} & \multicolumn{2}{|c|}{$\mathrm{R} 1_{\mathrm{t}}$} \\
\hline & Coeff. & t-stat & Coeff. & t-stat \\
\hline Intercept & 0.000 & 0.18 & 0.000 & 0.18 \\
\hline DCHAUDFEE $_{t}$ & 0.015 & $2.97^{* * *}$ & & \\
\hline DCHTOTFEE $_{t}$ & & & 0.013 & $4.16^{* * *}$ \\
\hline CHPMDA $_{t}$ & -0.000 & -0.25 & -0.000 & -0.24 \\
\hline $\mathrm{CH}_{\mathrm{t}-1}$ & 0.000 & 0.29 & 0.000 & 0.35 \\
\hline Obs & \multicolumn{2}{|c|}{3004} & \multicolumn{2}{|c|}{3004} \\
\hline Adj. $R^{2}$ & \multicolumn{2}{|c|}{$1.01 \%$} & \multicolumn{2}{|c|}{$1.29 \%$} \\
\hline
\end{tabular}


Panel B. Dependent variables $=\mathrm{R} 2_{\mathrm{t}}($ equation 3$)$

\begin{tabular}{|c|c|c|c|c|}
\hline & \multicolumn{2}{|c|}{$\mathrm{R} 2_{\mathrm{t}}$} & \multicolumn{2}{|c|}{$\mathrm{R} 2_{\mathrm{t}}$} \\
\hline & Coeff. & t-stat & Coeff. & t-stat \\
\hline Intercept & 0.000 & 0.36 & 0.001 & 0.36 \\
\hline DCHAUDFEE $_{t}$ & 0.079 & $2.12^{* *}$ & & \\
\hline DCHTOTFEE $_{\mathrm{t}}$ & & & 0.076 & $3.40^{* * *}$ \\
\hline $\mathrm{CHPMDA}_{\mathrm{t}}$ & -0.000 & $-0.000^{* *}$ & -0.000 & $-2.21^{* *}$ \\
\hline $\mathrm{CH}_{\mathrm{t}-1}$ & -0.000 & -0.81 & -0.000 & -0.75 \\
\hline Obs & \multicolumn{2}{|c|}{3004} & \multicolumn{2}{|c|}{3004} \\
\hline Adj. $\mathrm{R}^{2}$ & \multicolumn{2}{|c|}{$-0.43 \%$} & \multicolumn{2}{|c|}{$-0.19 \%$} \\
\hline
\end{tabular}

Note. $* * *, * *$, Coefficient is significant at the one percent level, the five percent level, the ten percent level respectively (one-tailed where signs are predicted, two-tailed otherwise).

Table 6 shows regression results of Equation 3. Panel A focuses on the residual from cash compensation. Each coefficient on DCHAUDFEE $(0.015$, t-statistic $=2.97, \mathrm{p}$-value $<0.01)$ and DCHTOTFEE $(0.013$, t-statistic $=$ 4.16. $\mathrm{p}$-value $<0.01)$ is significant and positive. Thus there is a positive relationship between changes in audit / total fees and variations of cash compensation after controlling financial and market impacts. This is consistent with the notion that auditors charge higher audit / total fees at the perception of higher firm risk, which in turn is positively related to discretionary accruals. Hence $\mathrm{H} 2$ is not true. The two control variables CHPMDA and $\mathrm{CH}$ do not have the significant coefficient.

In Panel B, the dependent variable is the residual from total compensation. Again, both DCHAUDFEE (0.079, t-statistic $=2.12, \mathrm{p}$-value $<0.05)$ and DCHTOTFEE $(0.076$, t-statistic $=3.40 . \mathrm{p}$-value $<0.01)$ have the significantly positive coefficients. This also rejects H2. Furthermore, CHPMDA is significant and negative even though the magnitude of the coefficient is very small. (Note 11). This is inconsistent with previous studies that find a positive relationship between CEO compensation and discretionary accruals. Our explanation is that since discretionary accruals and audit fee / total fees are highly correlated (Gul et al., 2003), audit / total fees have already captured the positive relation between discretionary accruals and CEO compensation. Totally speaking, all empirical evidence is not consistent with $\mathrm{H} 2$ and indicates that increases in audit / total fees are correlated with increases in cash / total compensation.

\section{Conclusions}

This paper examines the audit quality when auditors are considered as performing the monitoring role to mitigate discretionary accruals. The frequency analysis shows that auditors are likely to issue standard opinions except that before 1994 and after 2001 auditors are more conservative and issue more non-standard opinions. In addition, since 2004 auditors have charged higher audit fees for the internal control requirements of the Sarbanes-Oxley Act.

The empirical evidences about audit opinions suggest that modified opinions have significant impacts on CEO compensation. Cash compensation is $98 \%$ of prior cash compensation and total compensation is $96 \%$ of prior total compensation after auditors issue modified opinions. In addition, the incidence of going concern opinions affects the structure of compensation contracts. CEOs are granted more current incentive compensation relative to total compensation after the issuance of going concern opinions.

The regression results about audit or total fees also indicate that controlling earnings management is not the primary concern for auditors. Instead of preventing management from inflating earnings, auditors charge higher audit or total fees to compensate for higher audit risk associated with higher accounting accruals. Therefore, changes in audit or total fees are positively related to changes in cash or total compensation.

\section{References}

Antle, R., \& Nalebuff, B. (1991). Conservatism and Auditor-Client negotiations. Journal of Accounting Research, 29(Supplement), 31-54. http://dx.doi.org/10.2307/2491002

Ashbaugh, H., LaFond, R., \& Mayhew, B. (2003). Do Nonaudit Services Compromise Auditor Independence? Further Evidence. The Accounting Review, 78, 611-639. http://dx.doi.org/10.2308/accr.2003.78.3.611

Balsam, S. (1998). Discretionary Accounting Choices and CEO Compensation. Contemporary Accounting Research, 15(Fall), 229-252. http://dx.doi.org/10.1111/j.1911-3846.1998.tb00558.x

Becker, C., DeFond, M., Jiambalvo, J., \& Subramanyam, K. (1998). The Effect of Audit Quality on Earnings 
Management. Contemporary Accounting Research, 15(Spring), 1-24. http://dx.doi.org/10.1111/j.1911-3846.1998.tb00547.x

Bradshaw, M., Richardson, S., \& Sloan, R. (2001). Do Analysts and Auditors Use Information in Accruals? Journal of Accounting Research, 39(June), 45-74. http://dx.doi.org/10.1111/1475-679X.00003

Chen, C., Krishnan, G., \& Su, X. (2002). The Association Between Non-Audit Service Purchases and Managers' Compensation Structure. Working paper, City University of Hong Kong, Hong Kong.

Chung, H., \& Kallapur, S. (2003). Client Importance, Nonaudit Services, and Abnormal Accruals. The Accounting Review, 78, 931-955. http://dx.doi.org/10.2308/accr.2003.78.4.931

DeFond, M., \& Subramanyam, K. (1998). Auditor Changes and Discretionary Accruals. Journal of Accounting and Economics, 25, 35-67. http://dx.doi.org/10.1016/S0165-4101(98)00018-4

Dopuch, N., Holthausen, R., \& Leftwich, R. (1987). Predicting Audit Qualifications with Financial and Market Variables. The Accounting Review, 62(Autumn), 295-310.

Francis, J., \& Krishnan, J. (1999). Accounting Accruals and Auditor Reporting Conservatism. Contemporary Accounting Research, 16(Spring), 135-165. http://dx.doi.org/10.1111/j.1911-3846.1999.tb00577.x

Frankel, R., Johnson, M., \& Nelson, K. (2002). The Relation Between Auditors' Fees for Nonaudit Services and Earnings Management. The Accounting Review, 77(Supplement), 71-105. http://dx.doi.org/10.2308/accr.2002.77.s-1.71

Gaver, J., \& Gaver, K. (1998). The Relation between Nonrecurring Accounting Transactions and CEO Cash Compensation. The Accounting Review, 73(April), 235-253.

Gibbins, M., Salterio, S., \& Webb, A. (2001). Evidence About Auditor-Client Management Negotiation Concerning Client's Financial Reporting. Journal of Accounting Research, 39(December), 535-563. http://dx.doi.org/10.1111/1475-679X.00027

Gul, F., Chen, C., \& Tsui, J. (2003). Discretionary Accounting Accruals, Managers' Incentives and Audit Fees. Contemporary Accounting Research, 20(Fall), 441-464. http://dx.doi.org/10.1506/686E-NF2J-73X6-G540

Hopwood, W., \& McKeown, J. (1997). The Influence of Contrary Information and Mitigating Factors on Audit Opinion Decisions on Bankrupt Companies. Journal of Accounting Research, 35(Autumn), $295-310$. http://dx.doi.org/10.2307/2491367

Kim, J., Chung, R., \& Firth, M. (2003). Auditor Conservatism, Asymmetric Monitoring, and Earnings Management. Contemporary Accounting Research, 20(Summer), 323-359. http://dx.doi.org/10.1506/J29K-MRUA-0APP-YJ6V

Lennox, C. (1998). Modified Audit Reports, Executive Compensation and CEO Turnover. Working Paper. Bristol University, England.

Mutchler, J. (1985). A Multivariate Analysis of the Auditor's Going-Concern Opinion Decision. Journal of Accounting Research, 23(Autumn), 668-682. http://dx.doi.org/10.2307/2490832

Palmrose, Z. (1986). Audit Fees and Auditor Size: Further Evidence. Journal of Accounting Research, 24(Spring), 97-110. http://dx.doi.org/10.2307/2490806

Raghunandan, K., \& Subramanyam, K. (2002). Do Non-Audit Service Fees Impair Auditor Independence? Evidence from Going Concern Audit Opinions. Journal of Accounting Research, 40(September), 12471274. http://dx.doi.org/10.1111/1475-679X.00088

Simunic, D. (1980). The Pricing of Audit Services: Theory and Evidence. Journal of Accounting Research, 18(Spring), 161-190. http://dx.doi.org/10.2307/2490397

Wallace, W. (1987). The Economic Role of the Audit in Free and Regulated Markets: A Review. Research in Accounting Regulation, 1, 7-34.

\section{Notes}

Note 1. In the study of Francis and Krishnan (1999), modified opinions are audit opinions other than standard unqualified opinions and unqualified opinions with the explanatory paragraph for accounting policy changes.

Note 2. Bradshaw et al. (2001) indicate that a clean opinion is the standard unqualified opinion and an unclean opinion includes the qualified, adverse, or unqualified opinion with explanatory language. 
Note 3. Audit fees refer to charges for all kinds of services done by auditors, including audit fees, audit-related fees, non-audit fees, and fees for financial information systems design and implementation.

Note 4. The proxies for business complexity are different in each study. Simunic (1980) uses number of subsidiaries, industry diversity and foreign operation. Palmrose (1986) uses number of audit locations.

Note 5. Please refer to the index for the definition of each variable for equations (1)-(3).

Note 6. The current incentive compensation is the difference between total compensation and the sum of salary, other annual compensation, and all other total compensation.

Note 7. The equation is:

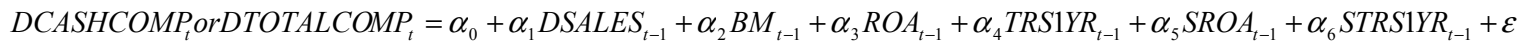

Where, DCASHCOMP/DTOTALCOMP is changes in cash compensation / total compensation deflated by total assets. DSALES is sales deflated by total assets.

Note 8 . The performance-matched discretionary accrual for one company is calculated by taking the difference of the discretionary accrual of this company and the discretionary accrual of another company matched by industry and year.

Note 9. Compensation data in 1992 is deleted because I need the data about economic conditions one year prior to the compensation data.

Note 10. Section 404 of Sarbanes-Oxley asks an auditor to evaluate the management assessment of intern controls and issue an internal control opinion in the $10-\mathrm{K}$ filing in 2004 for a company whose market capitalization is at least 75 million dollars.

Note 11. The magnitude of coefficient is less than 0.001 in each regression.

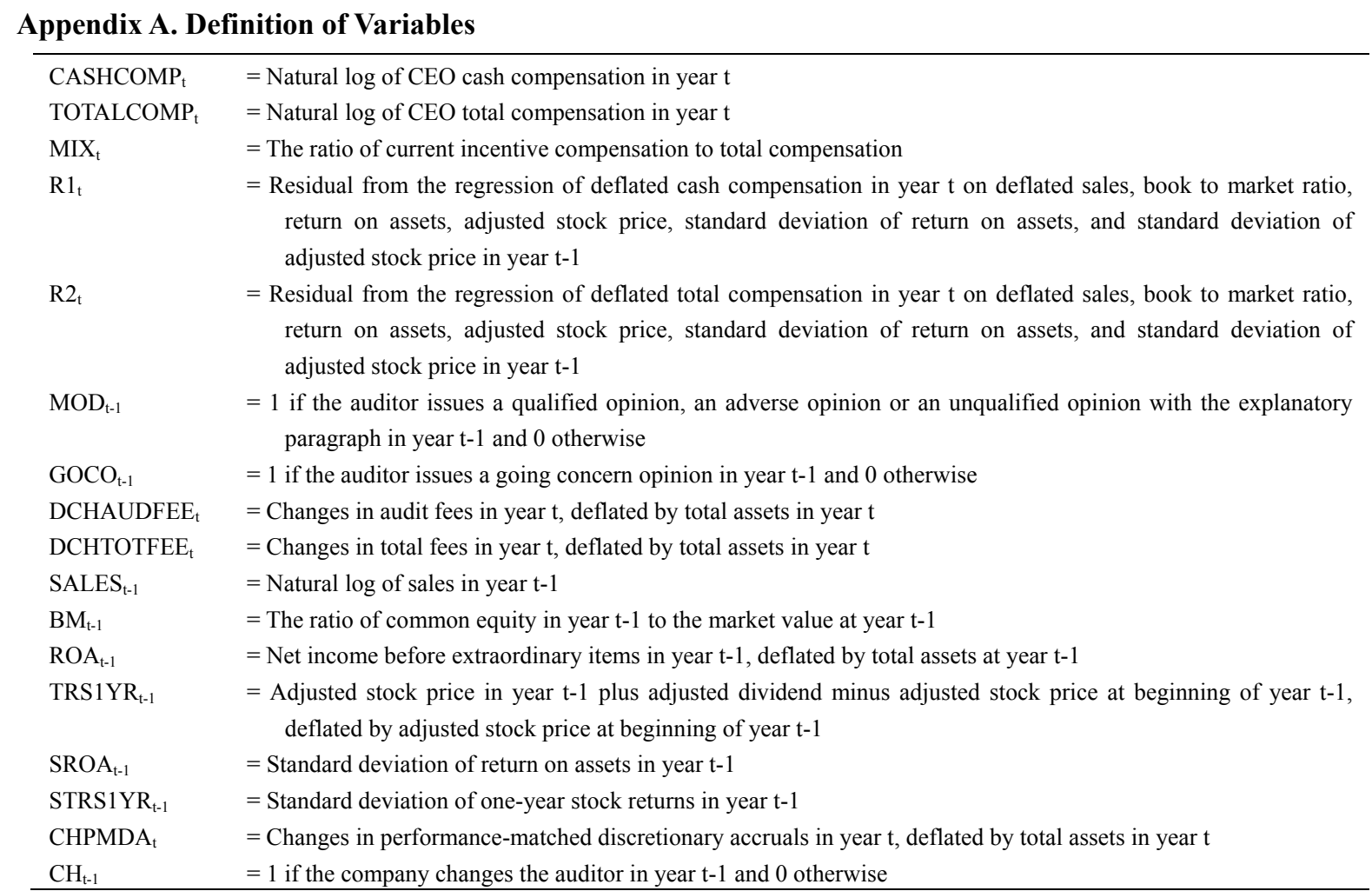

\section{Copyrights}

Copyright for this article is retained by the author(s), with first publication rights granted to the journal.

This is an open-access article distributed under the terms and conditions of the Creative Commons Attribution license (http://creativecommons.org/licenses/by/3.0/). 